\title{
Karakteristik Ikan Hasil Tangkapan Jaring Insang Hanyut di Perairan Kelurahan Tanjung Solok Kecamatan Kuala Jambi Kabupaten Tanjung Jabung Timur
}

\section{Characteristics of Fish Catched by Drift Gillnet in Tanjung Solok Kuala Jambi Tanjung Jabung Timur}

\author{
Novtia Kurniasih $^{1 *}$, Nurhayati ${ }^{1}$, Wiwaha Anas Sumadja ${ }^{1}$ \\ ${ }^{1}$ Pemanfaatan Sumberdaya Perairan, Fakultas Peternakan Universitas Jambi \\ *email:novtia14@gmail.com
}

\begin{abstract}
Abstrak
Diterima

28 Desember 2020

Kelurahan Tanjung Solok merupakan salah satu wilayah di Kuala Jambi yang menjadi lokasi pendaratan hasil tangkapan ikan. Salah satu alat tangkap yang paling banyak digunakan untuk menangkap ikan adalah jaring insang hanyut. Penelitian ini bertujuan untuk mengamati karakteristik hasil tangkapan ikan dengan jaring insang hanyut yang didaratkan di Kelurahan tanjung Solok. Analisis

Disetujui

02 Maret 2021 dilakukan secara deskriptif dengan metode pengambilan data survey dan random sampling. Mata jaring insang hanyut yang digunakan berukuran 4 inchi. Pengambilan data dilakukan pada 12 kapal sebanyak masing-masing 10 kali pengulangan. Hasil tangkapan yang didapatkan yaitu senangin, bawal putih, bawal hitam, tenggiri, malung, sebelah, dan parang dengan hasil tangkapan terbanyak yaitu bawal hitam sebanyak 1.143 ekor dan hasil tangkapan yang paling sedikit yaitu malung 75 ekor. Indeks keanekaragaman 1,66 termasuk dalam kategori sedang, sedangkan indeks dominansi 0,24 dalam kategori rendah. Ukuran panjang masing-masing ikan bervariasi. Dari penelitian yang telah dilaksanakan dapat disimpulkan bahwa karakteristik ukuran hasil tangkapan menunjukkan hasil yang bervariasi pada setiap spesies yang tertangkap dengan hasil tangkapan layak tangkap sebanyak 940 ekor (30\%), dan tidak layak sebanyak 2.212 ekor (70\%).
\end{abstract}

Kata kunci: Tanjung Solok, Jaring Insang Hanyut, Ukuran, Hasil Tangkapan

\begin{abstract}
Tanjung Solok sub-district is one of the areas in Kuala Jambi which is the landing location for fish. One of the most widely used fishing gear to catch fish is drift gillnets. This study aims to observe the characteristics of fish catches with drift gill nets landed in the Tanjung Solok sub-district. The analysis was carried out descriptively with survey data collection methods and random sampling. The gill mesh used is 4 inches in size. Data collection was carried out on 12 ships with 10 repetitions. The catches that were obtained were threadfin, white pomfret, black pomfret, mackerel, conger eel, flatfish, and dorab wolf-herring with the most catch was 1,143 black pomfret and the smallest catch was 75 conger eel. The diversity index of 1.66 is included in the medium category, while the dominance index is 0.24 in the low category. The length of each fish varies. Based on the research it can be concluded that the characteristics of catches by fish size shows that measure decent overall catch more than $30 \%$ and $70 \%$ are still in decent size has not been caught.
\end{abstract}

Keyword: Tanjung Solok, Drift Gillnet, Size, Catch 


\section{Pendahuluan}

Kecamatan Kuala Jambi memiliki luas wilayah 120,52 km², dengan batas wilayah utara Laut Cina Selatan, sebelah timur berbatasan dengan Kecamatan Muara Sabak Timur, sebelah selatan berbatasan dengan Kecamatan Muara Sabak Barat dan Kecamatan Muara Sabak Timur, dan sebelah barat berbatasan dengan Kecamatan Mendahara. Kelurahan Tanjung Solok memiliki luas daerah 37,56 km² dengan kondisi geografis daerah pesisir, sehingga sebagian masyarakatnya berprofesi sebagai nelayan (BPS, 2019).

Di Kelurahan Tanjung Solok, nelayan menggunakan alat tangkap jaring insang dan rawai. Alat tangkap jaring insang hanyut memiliki selektivitas ukuran yang cukup tinggi karena menangkap ikan yang sesuai dengan ukuran mata jaringnya dan meloloskan ikan yang lebih kecil, biaya operasinya murah dan juga hasil tangkapan sampingan yang sedikit. Tetapi, hasil tangkapan ikan yang didaratkan biasanya dalam keadaan mati dan juga terdapat luka fisik ditubuh ikan yang ditangkap. Hal ini dikarenakan lamanya waktu pengoperasian dan juga konstruksi jaring insang hanyut yang dapat melukai fisik ikan (Rusmilyansari, 2012).

Jumlah alat tangkap jaring insang hanyut yang meningkat dengan pesat menimbulkan kekhawatiran terjadinya overfishing / penangkapan secara berlebihan sehingga perlu adanya penelitian mengenai karakteristik hasil tangkapan untuk mengetahui keadaan hasil tangkapannya berupa hasil tangkapan utama, hasil tangkapan sampingannya, keanekaragaman, dominasi, dan apakah hasil tangkapan jaring insang hanyut ini telah mencapai ukuran layak untuk ditangkap.

Penelitian ini bertujuan untuk mengetahui karakteristik hasil tangkapan ikan yang ditangkap dengan jaring insang di kelurahan Tanjung Solok, Kecamatan Kuala Jambi, Tanjung Jabung Timur berdasarkan komposisi hasil tangkapan utama, sampingan dan hasil tangkapan terbuang, indeks keanekaragaman, indeks dominasi dan kelayakan ukuran hasil tangkapan.

\section{Bahan dan Metode}

\subsection{Waktu dan Tempat}

Penelitian dilaksanakan di kelurahan Tanjung Solok, kecamatan Kuala Jambi, kabupaten Tanjung Jabung Timur, pada tanggal 10 Agustus - 09 September 2020.

\subsection{Materi dan Peralatan}

Penelitian menggunakan ikan hasil tangkapan jaring insang yang didaratkan nelayan Tanjung Solok, peralatan yang digunakan yaitu jaring insang hanyut 4 inchi, timbangan dan penggaris sebagai alat pengukur panjang dan berat ikan, lalu buku tulis untuk mencatat, kamera sebagai alat dokumentasi, komputer untuk mengolah data.

\subsection{Metode Penelitian}

Penelitian dilakukan dengan metode survei. Penelitian ini dilakukan pengambilan sampel secara sensus atau total semua hasil tangkapan dari 12 kapal jaring insang hanyut 4 inchi masing-masing sebanyak 10 kali pengulangan. Pengambilan sampel kapal dilakukan secara acak dari keseluruhan kapal yang mendarat pada 4 gudang penampung ikan. Data berat diambil dengan menimbang total keseluruhan hasil tangkapan dan total hasil tangkapan setiap spesies. Pengukuran panjang dan berat perekor dilakukan secara keseluruhan ikan yang didaratkan. Peubah yang diamati berupa hasil tangkapan utama dan hasil tangkapan sampingan, indeks keanekaragaman, dominasi, panjang dan berat ikan yang tertangkap.

\subsection{Analisis Data}

Analisis dilakukan secara deskriptif. Analisis ini membedah dan menguliti suatu permasalahan untuk mendapatkan pembenaran terhadap keadaan dan praktek-praktek yang sedang berlangsung (Nazir, 2003). Hasil tangkapan sebelum dilakukan analisis terlebih dahulu diidentifikasi untuk mengetahui nama umum dan nama latin ikan. Pengidentifikasian dapat dilakukan secara langsung dengan mengamati ikan yang tertangkap kemudian dicari nama latin dan klasifikasinya melalui internet. Setelah dilakukan pengidentifikasian data tersebut dapat diolah dengan menggunakan software Microsoft excel untuk mengetahui komposisi hasil tangkapan dengan rumus yang dinyatakan oleh Odum et al. (1959):

$$
\begin{aligned}
& \text { Keterangan: } \\
& \mathrm{P}=\frac{\mathrm{ni}}{\mathrm{N}} \times 100 \% \\
& \begin{array}{ll}
\mathrm{P} & =\text { Presentasi relatif hasil tangkapan }(\%) \\
\mathrm{ni} & =\text { Jumlah hasil tangkapan perspesies }(\mathrm{i})(\mathrm{kg}) \\
\mathrm{N} & =\text { Jumlah seluruh hasil tangkapan }
\end{array}
\end{aligned}
$$

Untuk menentukan persentase $(\%)$ hasil tangkapan utama dapat dilakukan dengan rumus main catch rate: 
Keterangan:

$$
\mathrm{MR}=\frac{\Sigma \mathrm{Mc}}{\Sigma \mathrm{TNG}} \times 100 \%
$$

MR = Persentase hasil tangkapan utama

$\Sigma \mathrm{Mc} \quad=$ Total tangkapan utama

$\Sigma \mathrm{TNG} \quad=$ Total keseluruhan hasil tangkapan

Analisis Keanekaragaman Hasil Tangkapan dilakukan untuk menentukan keanekaragaman ikan yang dihasilkan oleh alat tangkap jaring insang, digunakan Indeks Diversitas Shannon-Wiener (Sylvia et al., 2017) dengan rumus sebagai berikut:

$$
\begin{gathered}
H^{\prime}=-\Sigma P i \operatorname{Ln} P i \\
H^{\prime}=-\Sigma\left(\frac{n i}{N}\right) \ln \left(\frac{n i}{N}\right)
\end{gathered}
$$

Keterangan:

$$
\begin{array}{ll}
\mathrm{H}^{\prime} & =\text { Indeks diversitas Shannon-Wiener } \\
\mathrm{ni} & =\text { Jumlah individu spesies ke-i } \\
\mathrm{N} & =\text { Jumlah individu semua spesies } \\
\mathrm{Pi} & =\frac{n i}{N}
\end{array}
$$

Jika $\mathrm{H}^{\prime}<1$ : kseanekaragaman rendah; $1 \leq \mathrm{H}^{\prime} \leq 3$ : keanekaragaman sedang dan $\mathrm{H}^{\prime}>3$ : keanekaragaman tinggi. Kriteria nilai indeks keanekaragaman Shannon (Wiyono et al., 2006). Analisis dominansi hasil tangkapan dilakukan untuk mengetahui spesies hasil tangkapan dominan yang dihasilkan oleh alat tangkap jaring insang, digunakan Indeks Dominansi Simpson (Ferianita, 2007) dengan rumus sebagai berikut :

Keterangan:

$$
\mathrm{c}=\sum_{\mathrm{i}=1}^{\mathrm{s}}\left(\frac{\mathrm{ni}}{\mathrm{N}}\right)^{2}
$$

$\begin{array}{ll}\mathrm{S} & =\text { Jumlah spesies } \\ \mathrm{c} & =\text { Indeks dominansi Simpson } \\ \mathrm{ni} & =\text { Jumlah individu spesies ke-i } \\ \mathrm{N} & =\text { Jumlah individu semua spesies }\end{array}$

Indeks dominansi simpson memiliki kisaran $\mathrm{D}<0,4$ : dominasi rendah; $0.4 \leq \mathrm{D} \leq 0,6$ : dominasi tinggi dan $\mathrm{D}>$ 0.6: dominansi tinggi. Analisis ukuran hasil tangkapan dilakukan untuk mengetahui ukuran selang panjang total dari setiap spesies ikan. Untuk menghitung jumlah dan interval kelas panjang ditentukan dengan menggunakan rumus sebagai berikut (Sylvia et al., 2017):

Keterangan:

$$
\begin{gathered}
\mathrm{K}=1+3,3 \log \mathrm{n} \\
\mathrm{i}=\frac{\mathrm{R}}{\mathrm{K}}
\end{gathered}
$$

$\begin{array}{ll}\mathrm{K} & =\text { Jumlah kelas } \\ \mathrm{N} & =\text { Banyak data } \\ \mathrm{i} & =\text { Interval kelas } \\ \mathrm{R} & =\text { Nilai terbesar }- \text { nilai terkecil }\end{array}$

Setelah ditentukan jumlah kelas dan interval kelas akan didapatkan rata-rata panjang ikan yang paling banyak tertangkap yaitu Lc.

\section{Hasil dan Pembahasan}

\subsection{Kondisi Umum Lokasi Penelitian}

Kelurahan Tanjung Solok memiliki luas daerah 37,56km² dari total wilayah Kecamatan Kuala Jambi 120,52 $\mathrm{km}^{2}$ dengan kondisi geografis daerah pesisir, dan sebagian masyarakatnya berprofesi sebagai nelayan (BPS, 2019). Kelurahan Tanjung Solok merupakan pusat pengumpulan dan perdagangan ikan hasil tangkapan nelayan. Secara geografis Kelurahan Tanjung Solok berada di muara Sungai Batanghari. Kondisi ini menjadikan Kelurahan Tanjung Solok sebagai perairan muara yaitu daerah pertemuan antara air sungai dan air laut (Katarina et al., 2019). Selain itu juga perairan Tanjung Solok merupakan perairan estuaria dengan dasar pantai yang landai dan bersubstrat lumpur. Substrat lumpur adalah kawasan yang kaya akan kandungan bahan organik dan memiliki keanekaragaman hayati yang tinggi (Putra et al., 2018). 


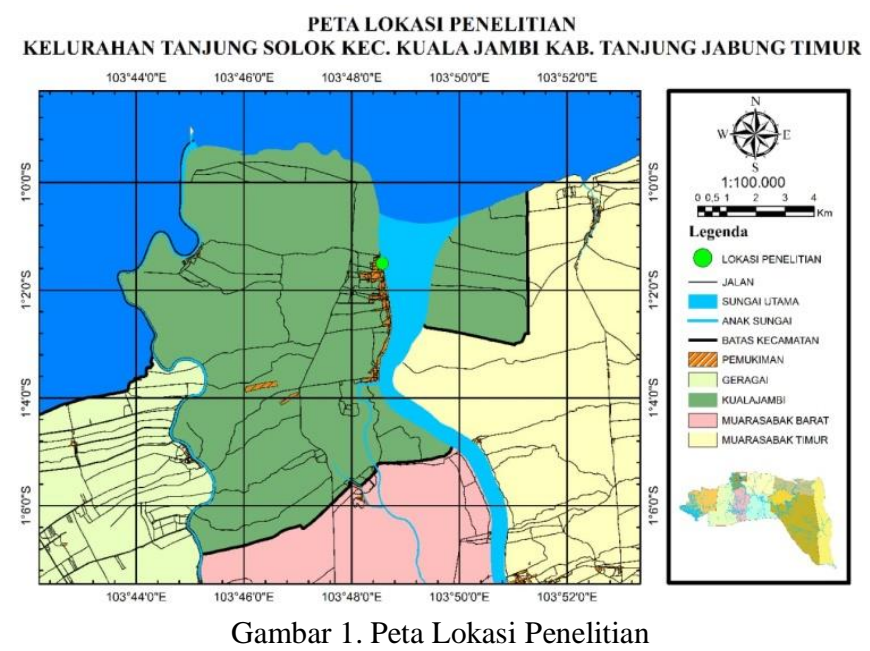

\subsection{Hasil Tangkapan}

Hasil tangkapan jaring insang hanyut terdiri dari berbagai macam jenis ikan dengan jumlah dan berat yang bervariasi. Komposisi hasil tangkapan jaring insang hanyut dapat dilihat pada Tabel 1.

Tabel 1. Komposisi Hasil Tangkapan Jaring Insang Hanyut

\begin{tabular}{|c|c|c|c|c|c|c|}
\hline No & Nama Ikan & $\begin{array}{c}\text { Jumlah } \\
\text { (ekor) }\end{array}$ & $\begin{array}{c}\text { Berat } \\
(\mathrm{g})\end{array}$ & Pi ekor & Pi berat & $\begin{array}{c}\text { Berat rata-rata } \\
\text { per ekor }(\mathrm{g})\end{array}$ \\
\hline 1 & Senangin (Eleutheronema tetradactylum) & 920 & 504.564 & $29,19 \%$ & $48,49 \%$ & 548,43 \\
\hline 2 & Bawal Putih (Pampus chinensis) & 227 & 62.336 & $7,20 \%$ & $5,99 \%$ & 274,60 \\
\hline 3 & Bawal Putih (P. argenteus) & 85 & 17.668 & $2,70 \%$ & $1,70 \%$ & 207,85 \\
\hline 4 & Bawal Hitam (Parastomateus niger) & 1.143 & 224.305 & $36,26 \%$ & $21,56 \%$ & 196,24 \\
\hline 5 & Tenggiri (Scomberomorus commerson) & 354 & 85.385 & $11,23 \%$ & $8,21 \%$ & 241,20 \\
\hline 6 & Malung (Muraenesox bagio) & 75 & 88.743 & $2,38 \%$ & $8,53 \%$ & $1.183,24$ \\
\hline 7 & Sebelah (Cynoglossus arel) & 91 & 14.878 & $2,89 \%$ & $1,43 \%$ & 163,49 \\
\hline 8 & Parang (Chirocentrus dorab) & 257 & 42.681 & $8,15 \%$ & $4,10 \%$ & 166,07 \\
\hline \multicolumn{2}{|c|}{ Jumlah } & 3.152 & 1.040 .560 & & & \\
\hline
\end{tabular}

Keterangan: Pi Ekor= Persentase komposisi ekor; Pi Berat= Persentase komposisi berat

Tabel 1menunjukkan bahwa hasil tangkapan dengan jumlah terbanyak adalah ikan bawal hitam sebanyak 1.143 ekor sedangkan untuk hasil tangkapan ikan berdasarkan berat adalah ikan senangin dengan berat total $504.564 \mathrm{~g}$ yaitu 504,564 kg. Untuk hasil tangkapan ikan dengan hasil paling sedikit dari segi berat yaitu ikan sebelah, dan dari jumlah yaitu ikan malung.

Menurut Katarina (2019) hasil tangkapan utama jaring insang hanyut yaitu ikan senangin. Sedangkan pada penelitian ini hasil tangkapan utama adalah 29,19\% dari total keseluruhan hasil tangkapan. Untuk hasil tangkapan sampingan adalah penjumlahan persentase komposisi hasil tangkapan sampingan yaitu 70,81\% dari keseluruhan hasil tangkapan. Katarina (2019) menyatakan senangin dan jenis bawal yang paling banyak tertangkap jaring insang pada kelurahan Tanjung Solok. Hal ini juga sesuai dengan pernyataan White (2013) bahwa ikan bawal hitam dan juga ikan senangin merupakan ikan yang mendiami area dengan substrat lumpur yang akan naik kepermukaan pada malam hari sebagaimana pengoperasian alat tangkap jaring insang hanyut yang dilakukan pada malam hari.

\subsection{Indeks Keanekaragaman dan Indeks Dominansi}

Indeks keanekaragaman dan juga indeks dominansi menentukan kondisi perairan lokasi penangkapan ikan. Nilai indeks keanekaragaman dan dominansi dapat dilihat pada Tabel 2.

Tabel 2. Nilai Indeks Keanekaragaman dan Dominansi Hasil Tangkapan Jaring Insang Hanyut

\begin{tabular}{ccc}
\hline Indeks & Nilai & Kategori \\
\hline H' (indeks Keanekaragaman) & 1,66 & Sedang \\
C (Indeks Dominansi) & 0,24 & Rendah \\
\hline
\end{tabular}

Nilai Indeks Keanekaragaman manunjukkan angka 1,66 yang artinya tingkat indeks keanekaragaman memiliki kategori sedang. Indeks keanekaragaman tergolong sedang diduga karena faktor kondisi lingkungan yang baik untuk ikan-ikan. Semakin tinggi nilai keanekaragaman menandakan bahwa kondisi lingkungan masih cukup baik untuk kehidupan berbagai spesies ikan dan keadaan ekosistem masih dalam keadaan stabil (Sylvia et 
al., 2017). Tinggi rendahnya nilai Indeks keanekaragaman jenis disebabkan oleh beberapa faktor, diantaranya jumlah jenis dan spesies yang ditemukan (Nurcaya et al., 2019).

Nilai indeks dominansi menunjukkan 0,24 yang artinya dominansi hasil tangkapan tergolong rendah. Meskipun begitu terdapat spesies dengan jumlah hasil tangkapan terbanyak yaitu Ikan bawal hitam dengan jumlah keseluruhan hasil tangkapan 1.143 ekor (36,26\%) dan ikan senangin dengan 920 ekor (29,19\%). Ketika kondisi lingkungan menurun menjadi kurang baik atau menjadi lebih buruk, biasanya timbul satu atau lebih jenis yang mendominasi komunitas karena jenis tersebut mampu bertahan dan berkembang, sehingga nilai keanekaragaman jenis menjadi menurun (Nurcaya et al., 2019).

\subsection{Ukuran Hasil Tangkapan}

Pada penelitian ini ukuran ikan yang tertangkap tertera pada Gambar 3-10. Terlihat bahwa ukuran ikan hasil tangkapan sangat bervariasi. Sehingga dilakukan pengelompokkan berdasarkan selang kelas ukuran panjang sesuai jenis ikan.

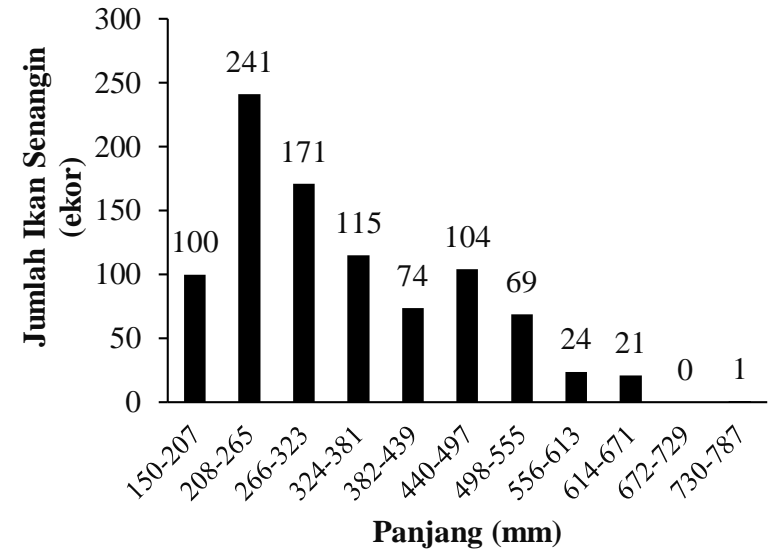

Gambar 2. Sebaran Ukuran Ikan Senangin (E. tetradactylum)

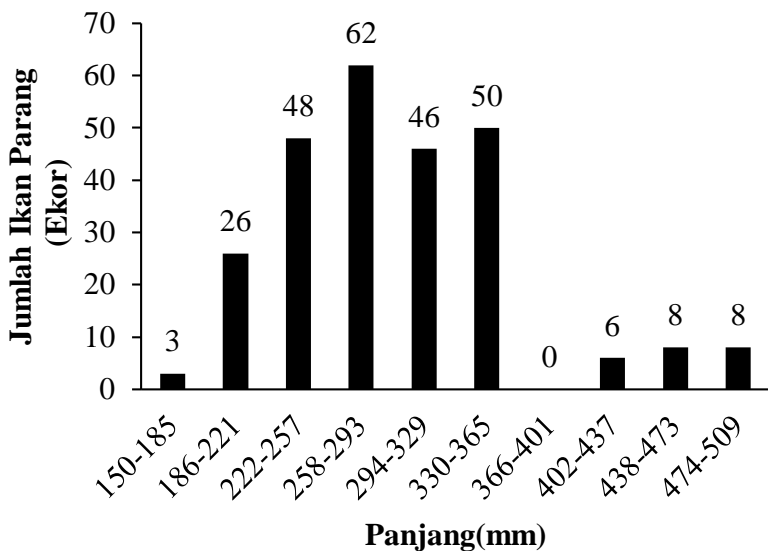

Gambar 3. Sebaran Ukuran Ikan Parang (C. dorab)

Ikan senangin yang tertangkap pada jaring insang hanyut paling banyak berukuran 208-265mm sebanyak 241 ekor dan yang paling sedikit berukuran 730-787 mm yaitu 1 ekor (Gambar 2). Ukuran 208-265 mm paling banyak tertangkap diduga karena ukuran mata jaring yang cukup besar sehingga meloloskan ikan yang berukuran kecil. Ikan senangin yang telah memasuki ukuran dewasa biasanya akan berdiam diri diperairan laut (Motomura, 2005). Hal ini juga sejalan dengan penelitian Sunarni dan Maturbongs, (2018) yang menyatakan bahwa ikan senangin merupakan ikan hermaprodit protandri. Ikan senangin kecil berjenis kelamin jantan dan hidup di daerah payau, sedangkan pada saat dewasa ikan senangin berjenis kelamin betina dan hidup di perairan laut.

Sebagaimana diketahui bahwa daerah penangkapan masih berada disekitaran muara sungai. Menurut (Motomura, 2005) ikan Senangin akan mengalami perubahan dari jantan ke betina pada tahun pertama kehidupannya dengan perkiraan panjang mulai 250-460 mm, sehingga dapat diperkirakan bahwa jumlah ikan yang paling banyak tertangkap masih digolongkan sebagai ikan senangin jantan yang mendiami perairan payau.

Gambar 3 menunjukkan bahwa ikan parang (Chirocentrus dorab) yang tertangkap pada jaring insang hanyut paling banyak berukuran 258-293 mm sebanyak 62 ekor dan yang paling sedikit berukuran 150-185 mm yaitu 3 ekor. Ukuran 258-293 mm paling banyak tertangkap diduga karena pada ukuran tersebut ikan parang akan lebih mudah terperangkap ke jaring insang hanyut. Ikan parang adalah ikan pelagis perairan pantai (White et al., 2013).

Ikan bawal putih yang tertangkap pada jaring insang hanyut paling banyak berukuran 174-200 mm sebanyak 94 ekor dan yang paling sedikit berukuran 336 -362 mm yaitu 3 ekor (Gambar 4). Ukuran 174-200 mm paling banyak tertangkap diduga karena spawning season P. chinensis terjadi pada post-monsoon (Angin muson timur) yaitu bulan Oktober hingga Januari (Prasetyo, 2020). Sedangkan penelitian dilakukan pada bulan Agustus sampai September sehingga ikan bawal putih yang banyak tertangkap masih dalam kategori di bawah first maturity lenght yaitu 174-200 mm. Menurut Prasetyo (2020) panjang ikan yang memasuki first maturity yaitu $280 \mathrm{~mm}$. Sehingga ikan tertangkap adalah ikan yang sedang dalam masa pertumbuhan menuju musim pemijahan atau spawning season karena jumlahnya sedikit, ukuran hasil tangkapannya juga masih dalam kategori yang kecil.

Ikan bawal putih yang tertangkap pada jaring insang hanyut paling banyak berukuran 167,25-193,5mm sebanyak 32 ekor dan yang paling sedikit berukuran 276,25-302,5 mm yaitu 3 ekor. Ukuran 167,25-193,5 mm paling banyak tertangkap diduga karena pada ukuran tersebut ikan masih dalam masa pertumbuhan sehingga banyak membutuhkan makanan yang memungkinkan ikan berada pada daerah penangkapan untuk mencari makan (Gambar 5). 
Menurut Amrollahi et al. (2007) Spawning season pada spesies P. argenteus terjadi pada bulan Mei hingga Oktober, dengan puncak musim pemijahan umumnya pada bulan Mei, Juni, dan Juli sehingga jumlah ikan yang tertangkap sedikit.

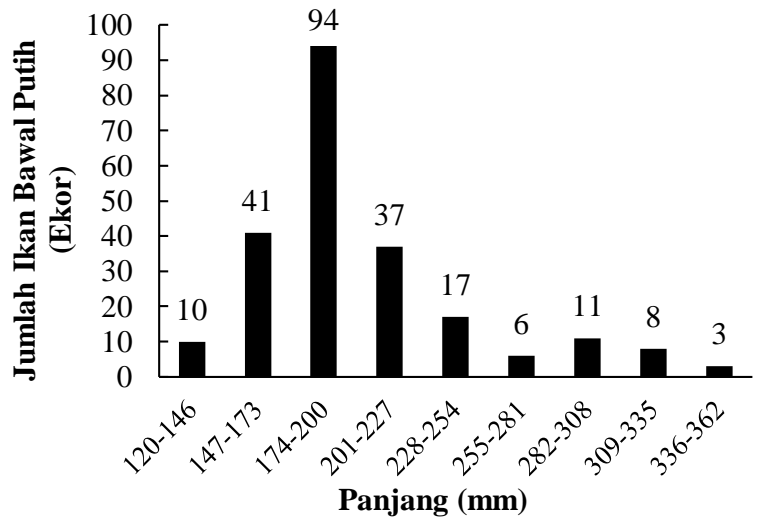

Gambar 4. Sebaran ukuran bawal putih (P. chinensis)

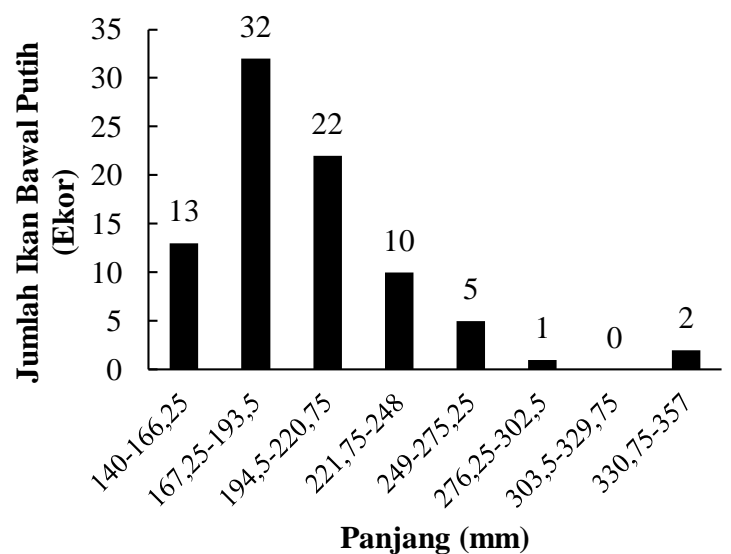

Gambar 5. Sebaran ukuran bawal putih (P. argenteus)

Ikan bawal hitam (P. niger) yang tertangkap pada jaring insang hanyut paling banyak berukuran 157-179,5 mm sebanyak 443 ekor dan yang paling sedikit berukuran 345-367,5mm yaitu 1 ekor (Gambar 6). Ukuran 157$179,5 \mathrm{~mm}$ paling banyak tertangkap diduga karena pada musim pemijahan pada ikan bawal hitam hampir sepanjang tahun yakni pada bulan Februari hingga September dengan puncaknya dibulan Maret dan Mei. Sehingga hasil tangkapan ikan bawal hitam cukup melimpah. Dengan puncak spawning season bulan Maret dan Mei memungkinkan jumlah ikan yang sedang dalam masa pertumbuhan sedang melimpah (Prasetyo, 2020).

Ikan tenggiri ( $S$. commersoni) yang tertangkap pada jaring insang hanyut paling banyak berukuran 266-297 mm sebanyak 91 ekor dan yang paling sedikit berukuran 394-425 mm dan 458-489 mm, yaitu 3 ekor (Gambar 7). Ukuran 266-297 mm paling banyak tertangkap diduga karena banyaknya ikan tenggiri bermigrasi untuk mencari makan ke daerah muara sungai karena pada penelitian Boesono, (2006) Ikan tenggiri memiliki panjang pertama kali matang gonad pada panjang $74,83 \mathrm{~cm}$ atau $748,3 \mathrm{~mm}$ yang artinya pada ukuran dibawah itu masih membutuhkan banyak asupan makanan.

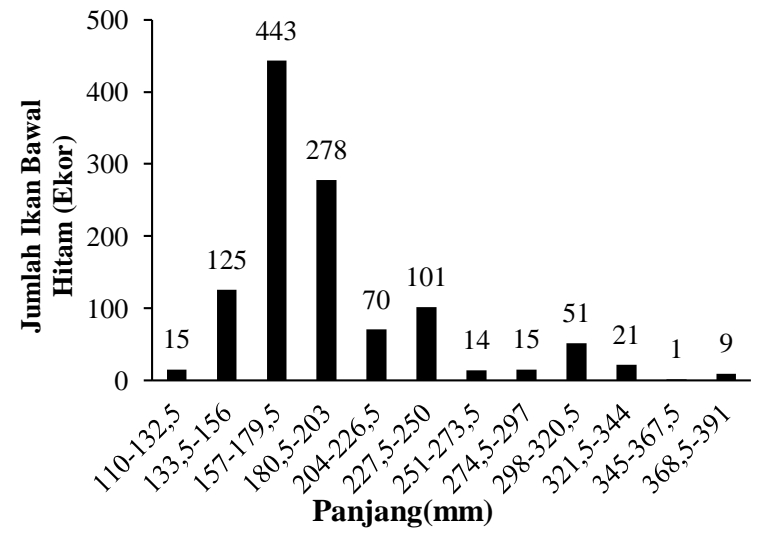

Gambar 6. Sebaran ukuran ikan bawal hitam (P. niger)

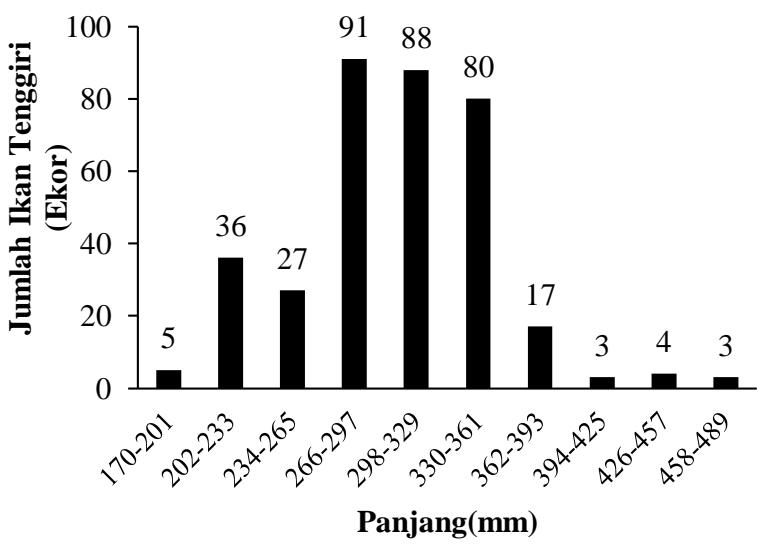

Gambar 7. Sebaran Ukuran Ikan Tenggiri (S.commersoni)

Gambar 8 menunjukkan bahwa ikan malung (M.bagio) yang tertangkap pada jaring insang hanyut paling banyak berukuran 757-839,5mm sebanyak 17 ekor dan yang paling sedikit berukuran 924-1006,5 mm yaitu 4 ekor. Ukuran 757-839,5mm paling banyak tertangkap diduga karenakan persebaran ikan malung yang tidak merata dan ikan malung merupakan salah satu jenis ikan demersal yang hidup hingga kedalaman $100 \mathrm{~m}$ di muara-muara sungai. Hal ini menyebabkan ikan malung yang tertangkap adalah ikan yang tengah berburu mencari makan ke dekat permukaan. Ikan ini termasuk jenis ikan predator yang memakan ikan-ikan lainnya malung mampu tumbuh hingga panjang $200 \mathrm{~cm}$ namun rata-rata panjangnya $100-150 \mathrm{~cm}$ dengan bentuk tubuh bulat memanjang seperti belut (Laksono et al., 2019).

Ikan sebelah (C. arel) yang tertangkap pada jaring insang hanyut paling banyak berukuran 339,75-363,5 mm sebanyak 32 ekor dan yang paling sedikit berukuran 387,25-411 mm yaitu 2 ekor. Ukuran 339,75-363,5 mm paling banyak tertangkap diduga karena ukuran mata jaring yang cukup besar sehingga meloloskan ikan dengan ukuran yang kecil. Selain itu juga tempat hidup ikan yang berada didasar perairan menjadikan hasil tangkapannya sedikit (Gambar 9). 


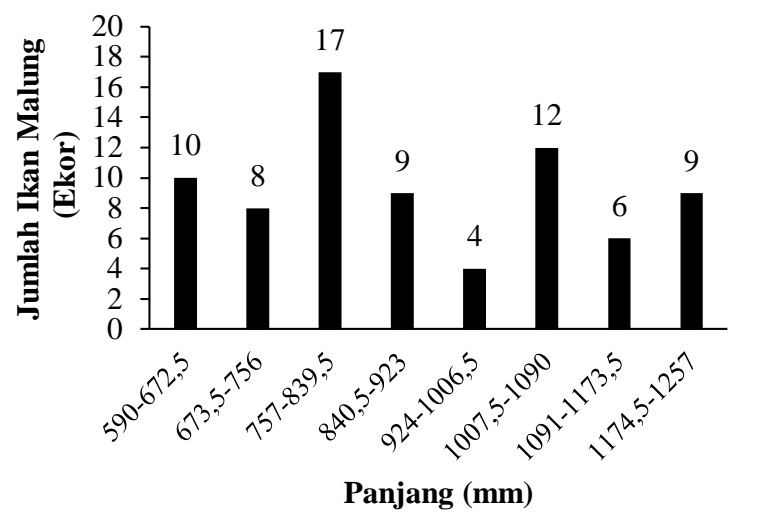

Gambar 8. Sebaran Ukuran Ikan Malung (M.bagio)

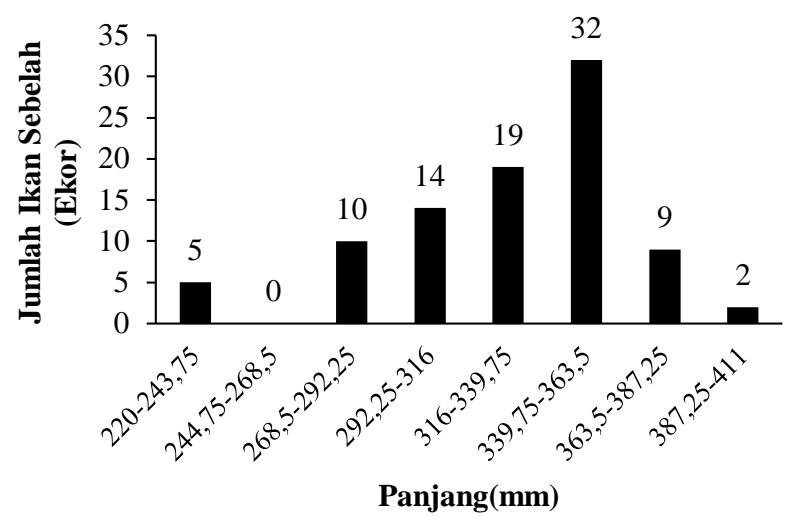

Gambar 9. Sebaran Ukuran Ikan Sebelah (C. arel)

Tabel 3. Kelayakan Hasil Tangkapan berdasarkan Nilai Lm

\begin{tabular}{|c|c|c|c|c|c|}
\hline \multirow{3}{*}{ Jenis ikan } & \multirow{3}{*}{$\mathrm{Lm}(\mathrm{mm})$} & \multicolumn{4}{|c|}{ Hasil Tangkapan } \\
\hline & & \multicolumn{2}{|c|}{ layak tangkap } & \multicolumn{2}{|c|}{ tidak layak tangkap } \\
\hline & & Jumlah (ekor) & $\%$ & Jumlah (ekor) & $\%$ \\
\hline Senangin & $250-460$ & 579 & $63 \%$ & 341 & $37 \%$ \\
\hline Bawal Hitam & 290 & 1046 & $8 \%$ & 1046 & $92 \%$ \\
\hline Bawal Putih(PC) & 280 & 22 & $10 \%$ & 205 & $90 \%$ \\
\hline Bawal Putih(PA) & 159,8 & 76 & $89 \%$ & 9 & $11 \%$ \\
\hline Tenggiri & $550-820$ & 0 & $0 \%$ & 354 & $100 \%$ \\
\hline Malung & $560-1060$ & 75 & $100 \%$ & 0 & $0 \%$ \\
\hline Sebelah & $191-210$ & 91 & $100 \%$ & 0 & $0 \%$ \\
\hline Parang & $590-690$ & 0 & $0 \%$ & 257 & $100 \%$ \\
\hline Jumlah Total & & 940 & $30 \%$ & 2.212 & $70 \%$ \\
\hline
\end{tabular}

Keterangan: Lm=Lenght of first maturity (Panjang pertama kali matang gonad) ; PC: P. chinensis; PA: P. argenteus Sumber: Fishbase

Tabel 3. Dapat dilihat bahwa dari total keseluruhan hasil tangkapan yaitu 3.152 ikan terdapat 940 (30\%) ikan yang telah memenuhi panjang pertama kali matang gonad dan yang belum memenuhi terdapat 1.263 (70\%). Untuk persentase hasil tangkapan layak terbanyak yaitu pada ikan malung dan ikan sebelah yang keseluruhan telah memenuhi kategori layak tangkap. Sedangkan untuk hasil tangkapan tidak layak terbanyak yaitu ikan tenggiri dan ikan parang. Masih terdapatnya ikan yang tidak layak tangkap diduga karena habitat dan tingkah laku ikan yang berbeda-beda, selain itu ukuran mata jaring kemungkinan besar mempengaruhi ukuran ikan yang tertangkap. Sebagaimana penelitian (Sylvia et al., 2017) yang menangkap menggunakan jaring insang berukuran 5 inchi menangkap lebih banyak ikan berukuran panjang layak tangkap.

\section{Kesimpulan}

Dari penelitian yang telah dilaksanakan dapat disimpulkan bahwa karakteristik hasil tangkapan ikan berdasarkan jenis ikan yang tertangkap oleh jaring insang hanyut ada 8 jenis spesies, yaitu ikan senangin ikan bawal putih, ikan bawal putih, ikan bawal hitam, ikan tenggiri, ikan malung, ikan sebelah dan ikan parang. Hal ini menunjukkan indeks keanekaragaman yang sedang dengan nilai 1,66 dan indeks dominansi rendah dengan nilai 0,24. Ukuran hasil tangkapan menunjukkan hasil yang bervariasi pada setiap spesies yang tertangkap dengan hasil tangkapan layak tangkap sebanyak 940 ekor (30\%), dan tidak layak sebanyak 2.212 (70\%).

\section{Saran}

Dikarenakan masih cukup banyak ikan ukuran kecil yang tertangkap, maka disarankan perlu diadakan penelitian lanjutan mengenai alat tangkap yang digunakan.

\section{Referensi}

[BPS] Badan Pusat Statistik. 2019. Kecamatan Kuala Jambi dalam Angka 2019. BPS Tanjung Jabung Timur. CV. Sumber Sentosa Multimedia.

Amrollahi, N., K. Preetha, M. Jasem, E. Gholam-Reza, dan Y. Vahid. 2007. Spawning Season of Pampus Argenteus (Euphrasen, 1788) in the Northwest of the Persian Gulf and its Implication for Management. Pakistan Journal of Biological Sciences, 10(24): 4551 - 4554. 
Boesono, D.H. 2006. Analisis Keramahan Alat Tangkap Jaring Tenggiri (Gillnet Millenium) di Perairan Pati terhadap Hasil Tangkapan.Departemen Perikanan Tangkap Fakultas Perikanan dan Ilmu Kelautan. Universitas Diponegoro Semarang.

Katarina, H., W.D. Kartika, dan T. Wulandari. 2019. Keanekaragaman Jenis Ikan Hasil Tangkapan Nelayan di Kelurahan Tanjung Solok Tanjung Jabung Timur. Biospecies, 12(2): 28 - 34

Laksono, U.T., T. Nurhayati, P. Suptijah, dan T.S. Nugroho. 2019. Karakteristik ikan Malong (Muraenesox cinerus ) sebagai Bahan Baku Pengembangan Produk Diversifikasi Rial for Diversification Products Development. Jurnal Pengolahan Hasil Perikanan Indonesia, 22(1):60-70.

Motomura, H. 2005. An Annotated And Illustrated Catalogue. Food Agric. Organ. United Nations 1, 262 P. 9 Colour Plates.

Myers, P., R. Espinosa, C.S. Parr, T. Jones, G.S. Hammond, dan T.A. Dewey. 2020. The Animal Diversity Web (online). Accessed at https://animaldiversity.org.

Nurcaya, E., W. Nurgayah, dan H. Arami. 2019. The Species Composition and Fish Community Structure in the Seagrass of Banabungi Village Waters, Kadatua Sub-District, Buton Selatan Regency. Sapa Laut, 4(4): 175-185.

Odum, E.P. 1959. Fundamentals of Ecology. J. Range Manag.

Putra L.E., T.A Maryani, dan H. Syarifuddin. 2018. Analisis Indeks Kepekaan Lingkungan (IKL) pesisir Pantai Tanjung Jabung Timur Provinsi Jambi terhadap Tumpahan Minyak (oil spill). Jurnal Pembangunan Berkelanjutan,1(1):26-38

Rusmilyansari. 2012. Inventarisasi Alat Tangkap Berdasarkan Kategori Status Penangkapan Ikan yang Bertanggung jawab di Perairan Tanah Laut. Journal Fish Scientiae, 2(4):143-153

Sunarni, S., dan M.R. Maturbongs. 2018. Pertumbuhan dan Tingkat Kematangan Gonad Ikan Kuro (Eleutheronema tetradactylum) di Daerah Estuari Pesisir Pantai Kota Merauke. Musamus Fish and Marine Journal, 1(1): 15-23.

Sylvia, N., C. Marwan, dan R. Aprilla. 2017. Analisis Hasil Tangkapan Jaring Insang di Kuala Baru Kabupaten Aceh Singkil. Jurnal Ilmiah Mahasiswa Kelautan dan Perikanan Unsyiah, 2(3): 415-422

White, W.T., P.R. Last, Dharmadi, R. Faizah, U. Chodrijah, B.I. Prisantoso, J.J. Pogonoski, M. Puckridge, S.J.M. Blaber. 2013. Market Fishes of Indonesia (Jenis-Jenis Ikan Di Indonesia). $438 \mathrm{hlm}$.

Wiyono, E.S., S. Yamada, E. Tanaka, T. Arimoto, and T. Kitakado. 2006. Dynamics of Fishing Gear Allocation by Fishers in Small-Scale Coastal Fisheries of Pelabuhanratu Bay, Indonesia. Fisheries Management and Ecology Blackwell Publishing Ltd., London. 3 : 185-195 